\title{
Evaluation of mixtures of lateritic clayey soil with quartzite and stone powder for road purposes
}

\section{Fernando Augusto Corrêa ${ }^{1}$, Ana Carina Zanollo Biazotti Collares ${ }^{2}$, Eduardo Goulart Collares ${ }^{3}$, Rogério Pinto Ribeiro ${ }^{4}$, Fernanda Medeiros Dutra Reis ${ }^{5}$}

1 University of Sao Paulo, São Paulo, Brazil, fernandoaugustocorrea@usp.br ${ }^{2}$ Minas Gerais State University, Minas Gerais, Brazil, collaresambiental@hotmail.com ${ }^{3}$ Minas Gerais State University, Minas Gerais, Brazil, collaresambiental@hotmail.com 4University of Sao Paulo, São Paulo, Brazil, rogerioprx@sc.usp.br ${ }^{5}$ University of Sao Paulo, São Paulo, Brazil, fernandamdreis@hotmail.com

\section{Recebido:}

8 de junho de 2019

Aceito para publicação:

30 de abril de 2020

Publicado:

31 de agosto de 2020

Editor de área:

Kamilla Vasconcelos

\section{Keywords:}

MCT Classification.

Soil-Residue.

Quartzite.

Stone Powder.

\section{Palavras-chaves:}

Classificação MCT.

Solo-Resíduo.

Quartzito.

Pó de Pedra.

DOI:10.14295/transportes.v28i3.2088 OPEn 2 access

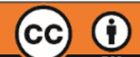

\begin{abstract}
This study evaluated the viability of using the fine residue of quartzite and stone powder from dunite mining in the southwest region of the State of Minas Gerais, Brazil, as aggregates mixed with Lateritic Clayey Soil for the treatment of base and sub-base layers of low-volume traffic pavement. Mixtures were prepared with soil and residues, in different proportions, tested in laboratory as proposed by MCT (Miniature, Compacted, Tropical) methodology for classification and to obtain some geotechnical properties. The results showed the potential replacement of conventional aggregate, since the samples evaluated were classified as "satisfactory" and/or "recommended" according to MCT, opening perspectives for a wider utilization of waste and by-products from quartzite slab production and ultrabasic rock aggregates.
\end{abstract}

\section{RESUMO}

Este trabalho tem por objetivo estudar a viabilidade de uso do resíduo fino de quartzito e do pó de pedra de dunito de minerações da região Sudoeste do estado de Minas Gerais - Brasil, como agregados misturados ao Solo de Comportamento Laterítico Argiloso (LG') no tratamento de camadas de base e sub-base de pavimentos de baixo volume de tráfego. Foram preparadas misturas com o solo e os resíduos em proporções distintas e realizados ensaios laboratoriais propostos na metodologia MCT (Miniatura, Compactado, Tropical) para classificação e obtenção de algumas propriedades geotécnicas. Os resultados alcançados apontam para a potencial substituição do agregado convencional, visto que as amostras avaliadas enquadraram-se nas classes "satisfatórias" e/ou "recomendadas" da Classificação MCT, abrindo perspectivas de um aproveitamento mais amplo dos resíduos e sub-produtos da produção de placas de quartzitos e agregados de rochas ultrabásicas.

\section{INTRODUCTION}

Rock mining, especially in the State of Minas Gerais, produces a large amount of tailings, due to the rudimentary process of extraction and exploration, resulting in considerable environmental liabilities. On the other hand, the increasing growth in the consumption of aggregates has motivated the development of studies aiming at the use of alternative materials, with lower cost, good quality and preferably sustainable, from the recycling of waste (Collares et al., 2008a, 2008b; Francklin Junior, 2009; Francklin Junior et al., 2010; Coladetti and Collares, 2015; Grilo, 2016).

In this context, the present study proposed to evaluate the technical feasibility of using the residues from the exploitation of foliated quartzite slabs and stone powder (derived from dunite 
mining as a fine aggregate), replacing the traditional aggregate (sand), mixed with a Lateritic Clayey Soil ( $\left(G^{\prime}\right)$, for use in the treatment of low-traffic pavement layers in the southwest region of the State of Minas Gerais. The study was carried out using the MCT methodology - Miniature, Compacted, Tropical (Nogami and Villibor, 2009) for classification and to obtain properties for checking the classification into the "satisfactory" and/or "recommended" areas.

The future implementation of the research results is expected to produce economic and environmental benefits. In relation to quartzite, whose waste represents about $90 \%$ of the extracted material, in addition to the environmental and economic benefits, with the availability of a low-cost product on the market, there will be a great social benefit for the region, since it will allow reintegration of employees who were fired for irregular mining activity, which were closed by environmental agencies or had their quarries exhausted.

As for stone powder, data obtained from a mining located in the municipality of Pratápolis, State of Minas Gerais, reveal that stone powder and crushing fines correspond to approximately $35 \%$ of the exploited material. Due to the difficulties in commercialization, this material accumulates in areas adjacent to the mine, which generates environmental impacts such as siltation of rivers and suppression of vegetation for new deposit areas.

\section{LOW COST PAVEMENT AND THE MCT METHODOLOGY}

Santana (1993) considers low-cost pavement to be the one that, in its construction, uses local and alternative materials, with regional technologies and experiences, seeking a minimum cost compared to traditional methods. Batalione et al., (2010) explain that, in Brazil, low-cost pavement is related to fine sandy lateritic soil (SAFL), in the production of pavement structures with scarcity of granular material quarries and low to medium traffic volume. According to Villibor et al., (2009), there are lateritic fine soils that do not have adequate characteristics for use as a base for pavements, but which, if mixed with each other or with sands, can behave similarly to SAFL soils.

According to Nogami and Villibor (1995), only the traditional study, with indices of consistency and grain size by sieving, did not demonstrate the qualities corresponding to the real performance of tropical soils. Therefore, the authors proposed a new classification of soils for road purposes called MCT - Miniature, Compacted, Tropical. In their research, they used lateritic clayey and sandy soils used in subgrade reinforcement layers and pavement sub-base. As a result, an excellent behavior was found, reaching high load-bearing capacity (CBR) for varieties of clay-sandy soils and clays. Therefore, in the late 1960s, lateritic soils were also adopted for the construction of bases on sections of highways and urban roads.

Nogami and Villibor (1995) also used on the base layer with local soils, thin coatings of sealed bituminous macadam, and surface treatments, reducing implementation costs. In 1970, the Highways Department of São Paulo State - DER applied the methodology in local roads, enabling the assessment of performance in situ. After a few years of using these tropical soils, a proprietary technology was developed, which, improved, resulted in the current MCT methodology developed by Nogami and Villibor, and since then it has been used by road agencies and city halls (Villibor et al., 2009).

\section{IMPACTS ON MINING AND ALTERNATIVE USE OF RESIDUES}

Environmental degradation is an intrinsic factor of mining activity; thus, the concern with environmental management becomes very important. These projects have an exploration cycle 
and, after that period, many facilities are abandoned without any process for restoring degraded areas (Tonidanvel, 2011). The impacts of mining companies are observed in the physical, biotic and anthropic environments, being negative and irreversible. The visual degradation is the most expressive, as there is the exposure of the rocky front of exploitation and the mining send-off creates a desert scenario, with an arid aspect. (Alecrim and Fabri, 2004).

The main negative impacts caused by mining are: stripping; biodiversity loss; contamination of soil, surface and groundwater; suppression of vegetation cover; noise and visual pollution; among others. On the other hand, there are positive impacts with the generation of jobs and taxes, improving the economic and social development in the region. However, the main concern is the future rehabilitation of the area, considering the environmental quality, safety and development of the surroundings (FEAM, 2011).

Currently, the generation of waste is the main challenge for industries that exploit quartzite, due to the low use of the extracted material, which leads to a series of problems such as: environmental degradation, low profit, less use of quarries in relation to the product/volume explored, difficulty in obtaining environmental certifications for export, logistics for waste disposal and closing the mine, since the current legislation holds the mining company responsible also after the end of production activities; however, justifying their maintenance, these quarries generate jobs, increasing the local economy (Russo, 2011; Alecrim et al., 2006).

Bernucci et al., (2010) emphasize the existence of alternative materials of increasing use in paving, resulting from reuse and recycling: blast furnace slag; aggregate from construction and demolition solid waste; waste from dimension stones exploitation, such as quartzite; asphalt mixture, among others.

Alecrim et al., (2009) and Alecrim (2009) investigated the use of quartzite waste as material for pavements. For that, they analyzed soil-residue mixtures, in different proportions, with discontinuous particle size, according to Nogami and Villibor (1995) proposal, and continuous, according to traditional stabilization criteria. The proportions analyzed were $30 \%, 40 \%$ and $50 \%$ of soil and $70 \%, 60 \%$ and $50 \%$ of quartzite, respectively. Laboratory compaction, California Bearing Ratio and Resilient Modulus tests were performed. The results indicated that the grain size distribution of the aggregates has no significant influence on the mechanical properties of the mixtures and the values obtained were satisfactory for resistance and deformability, comparable to traditional granular materials and soil-aggregate mixtures. In conclusion, the studied waste is an alternative for use in sub-bases or flexible bases of pavements.

Collares et al., (2012) evaluated the quartzite mining waste in the Southwest region of the State of Minas Gerais to check the possibility of recycling these materials as coarse aggregate in Portland cement concrete. In general, results were positive when compared to the conventional aggregate of gneiss, as well as the workability and properties in the hardened state; the compressive strength values ranged from 22.3 $\mathrm{MPa}$ to 24.4 $\mathrm{MPa}$; tensile strength ranged from 1.98 $\mathrm{MPa}$ to $2.38 \mathrm{MPa}$; and the modulus of elasticity from $13.91 \mathrm{GPa}$ to $16.54 \mathrm{GPa}$. The study showed a satisfactory behavior with the use of the waste, but it was necessary, to consider the site of collection of the material, since the traces of two samples, denominated A1 and A3, showed values lower than the gneiss trace (conventional), while the traces A2 and A4 presented an increase in the tensile strength in relation to the standard trace.

Reis (2016) and Reis et al., (2018a, 2018b) sought alternatives to reduce the problems related to the disposal and reuse of mining waste, analyzed the technical feasibility of using 
quartzite residue as coarse and fine aggregate for the production of Concrete Block Paving (CBP) to replace conventional aggregates, and obtained results that indicated the possibility of $100 \%$ replacement of coarse aggregate, since there were no differences in simple compressive strength in relation to conventional material. For the fine aggregate, washed and unwashed quartzite sand were used, and no significant differences were detected, with the difference of a better surface finish of the pieces for the unwashed material.

Russo (2011) studied applications for quartzite mining tailings from the Serra da Canastra region as aggregate. The samples were characterized physically, chemically and mineralogically. Tests were carried out for workability, compressive strength, degradation, abrasion, loss to shock and shape index in mortars. With the exception of the elongated dimensions of the coarse aggregate obtained, the results were positive, indicating the possibilities of using the waste for the production of precast concrete, industrialized mortars and pavements.

Grilo (2016) investigated the use of fine fraction of the quartzite mining tailings from the Southwestern region of Minas Gerais as fine aggregate in soil-residue mixtures with the local lateritic clayey soil to replace sand in the ALA (Sand Lateritic Clay with Sand) composition of the MCT methodology for pavement base in low traffic roads, comparing the performance of mixtures composed of quartzite residue in relation to mixtures with river washed sand, traditionally used. The values obtained in the tests, for example, in the Mini-CBR test, demonstrated the potentiality of using the fine aggregate of quartzite quartzite mining tailings as pavement base, presenting better results than with natural soil; in which soil-sand and soilquartzite mixtures were analyzed in the proportions of $85 \%$ x 15\%, 70\% x 30\% and 55\% x 45\%. Of these mixtures, those containing $30 \%$ and $45 \%$ residue were considered satisfactory for use as pavement base.

\section{MATERIALS AND METHODS}

Figure 1 shows the map with the location of the study area:

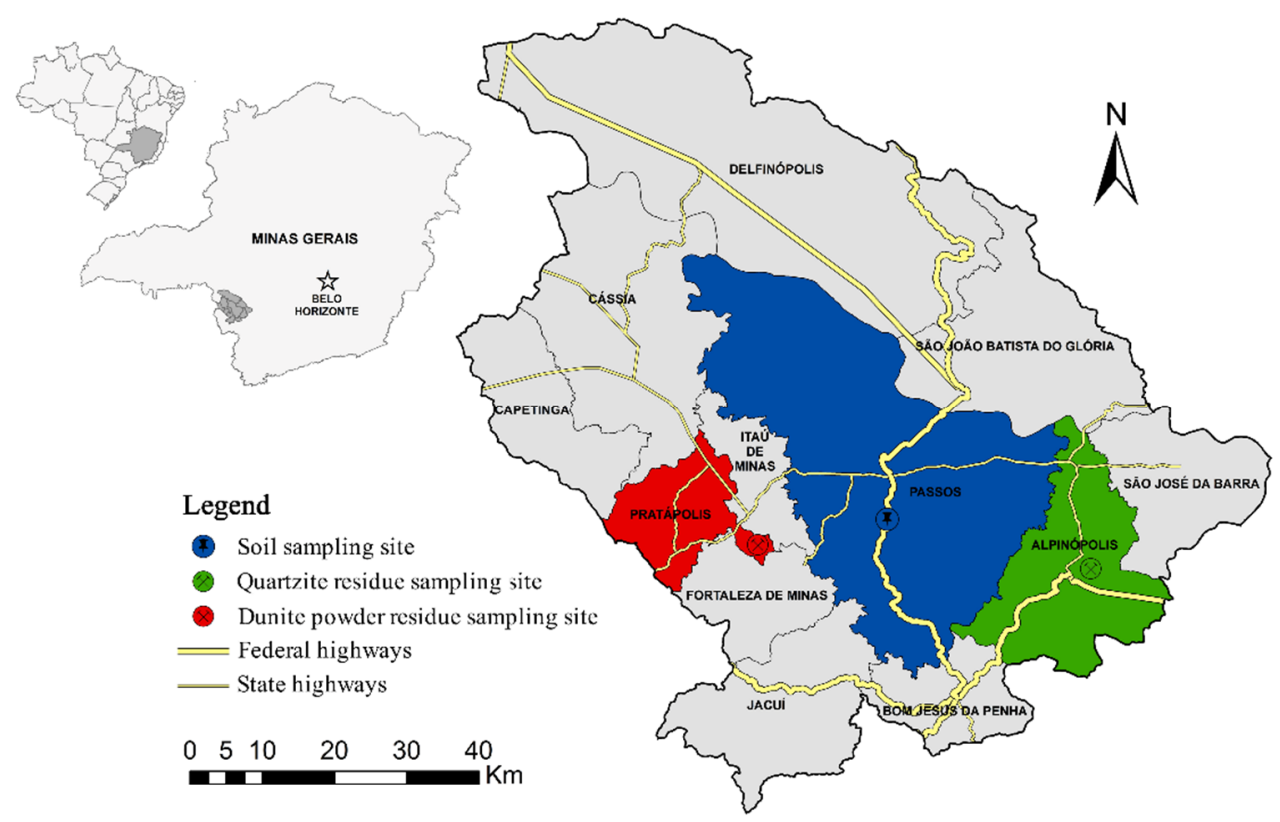

Figure 1. Location of the study area, the approximate distance between the sampling sites of the fine fraction of quartzite mining and stone powder (dunite) to the soil sampling sites were $52 \mathrm{~km}$ and $38 \mathrm{~km}$, respectively 


\subsection{Sampling the materials \\ 4.1.1. Soil}

Soil was collected on the margins of the Domingo Ribeiro Resende Highway (BR-146), $4.5 \mathrm{~km}$ from Passos, State of Minas Gerais, towards Bom Jesus da Penha, State of Minas Gerais, at the coordinates $20^{\circ} 47^{\prime} 36.1^{\prime \prime} \mathrm{S}$ and 4636'23.8' W. To choose and define the sampling site, we used the previous studies carried out by Grilo (2016), who had already classified this soil as Lateritic Clay Soil (LG'), a soil very commonly found in the region of Passos, State of Minas Gerais. This soil was used as loan material during the paving of this highway. The collection was carried out based on the DNER-Pro 003 standard (DNER, 1994).

\subsubsection{Sand}

We used sand from a construction material deposit. Sand samples were acquired by Grilo (2016) and also used in this research. The soil-sand mixture was the comparison parameter for soil-residue mixtures.

\subsubsection{Quartzite}

The quartzite waste was collected in a mining located in the municipality of Alpinópolis, Southwest region of the State of Minas Gerais, on the Chapadão Farm (geographic coordinates 2051'15.818" S and 46-21'11.390" W). Mining is carried out using surface mining, with explosives and excavators. The quartzite blocks are peeled and cut manually. The material used in this research was collected by Grilo (2016).

\subsubsection{Stone powder (Dunite)}

Dunite powder was collected in a quarry at Morro Azul Mining (geographic coordinates $20^{\circ} 49^{\prime} 29,237^{\prime \prime}$ S and $46^{\circ} 46^{\prime} 4,768^{\prime \prime}$ W), located in the municipality of Pratápolis, State of Minas Gerais, which represents the basal portion from the Morro do Níquel deposits, where lateritic nickel ore has been mined for some decades (Faria Júnior, 2011). At the site, a stripping of about $20 \mathrm{~m}$ deep was carried out, which allowed the exposure of the rock mass, suitable for stone production.

\subsection{Mixture Production: Lateritic Clayey Soil + Aggregates}

To carry out the tests, the Lateritic Clayey Soil ( $\left.L G^{\prime}\right)$ was mixed with the aggregates in different proportions, consisting of river washed sand, fine fraction of the quartzite mining and stone powder (dunite) residues, thus resulting in the following samples:

$(S)$ Soil; $(A)$ Sand; $(Q)$ Quartzite and $(D)$ Dunite.

$S 100 \rightarrow 100 \%$ Lateritic Clayey Soil;

$S 70 D 30 \rightarrow 70 \%$ Lateritic Clayey Soil $+30 \%$ dunite powder residue;

$S 60 A 40 \rightarrow 60 \%$ Lateritic Clayey Soil $+40 \%$ river washed sand;

$S 60 Q 40 \rightarrow 60 \%$ Lateritic Clayey Soil $+40 \%$ quartzite residue;

$S 60 D 40 \rightarrow 60 \%$ Lateritic Clayey Soil $+40 \%$ dunite powder residue;

$S 50 A 50 \rightarrow 50 \%$ Lateritic Clayey Soil $+50 \%$ river washed sand;

$S 50 Q 50 \rightarrow 50 \%$ Lateritic Clayey Soil + 50\% quartzite residue;

S50D50 $\rightarrow 50 \%$ Lateritic Clayey Soil + 50\% dunite powder residue. 
It should be noted that the mixture consisting of $70 \%$ soil and $30 \%$ aggregate was used only for stone powder (dunite), since this proportion with river washed sand and fine fraction of the quartzite mining tailings was previously studied by Grilo (2016).

\subsection{Tests, characterization and classification of mixtures}

\subsubsection{Grain size analysis}

The mixtures were subjected to readings of the symmetrical bulb hydrometer immersed in the solution containing the soil particles. The readings thus determined, together with data on the temperature of the solution during the test and data related to the calibration of the hydrometer used, comprised the database necessary for calculating the percentages of the particle sizes defined by the technical standard NBR 7181 (ABNT, 2018).

\subsubsection{Proctor compaction test}

The test was performed based on the NBR 7182 standard (ABNT, 2020). Samples were compacted at Normal energy, small rammers and cylindrical mold, in 3 layers, applying 26 blows in each one, in order to obtain the optimum water content and the dry density for each mixture.

\subsubsection{Mini-MCV compaction test}

The test was performed according to DNER-ME 258 (DNER, 1994). Samples were compacted, using a light weight rammer, with a sequence of increasing number of blows. From the test, we obtained a family of compaction curves and the empirical coefficients $c^{\prime}$, which is the slope of the most inclined, straight portion of the sink curve, corresponding to the optimum water content that results in the Mini-MCV equal to 10, and $d^{\prime}$, which is the slope of the most inclined straight portion of the dry branch of the compaction curve, corresponding to 12 blows on the graph.

\subsubsection{Mass loss test by immersion in water}

The test was performed according to DNER-ME 256 (DNER, 1994). After the Mini-MCV test, the compacted specimen was extracted, $10 \mathrm{~mm}$ from its respective mold was submerged in water, horizontally. After 24 hours, the capsule with the detached mass was taken and the dry mass was determined. From this test, the Pi coefficient, expressed as a percentage, was calculated, which is the proportion of dry mass detached in relation to the extruded mass, using a correction factor depending on the type of detachment observed, aiming at the classification and prediction of surface stability of the soil to weathering.

With the results of these last two tests, samples were classified according to the MCT Classification of Tropical Soils (Nogami and Villibor, 1995).

\section{RESULTS AND DISCUSSION}

The results of the tests are presented below, following the order of the methodology used in the study.

Initially, Figure 2 illustrates the curves of the grain size composition of the samples. Table 1 lists their respective values. Figure 3 shows the Proctor compaction curves, and Table 2 presents the values of maximum dry density and optimum water content. Table 3 lists the values of the Mini-MCV, Mass Loss by Immersion and the MCT Classification. 
Figure 4 shows the classification of the samples in the satisfactory or recommended areas, according to the Tropical Soil classification of Nogami and Villibor (1995).

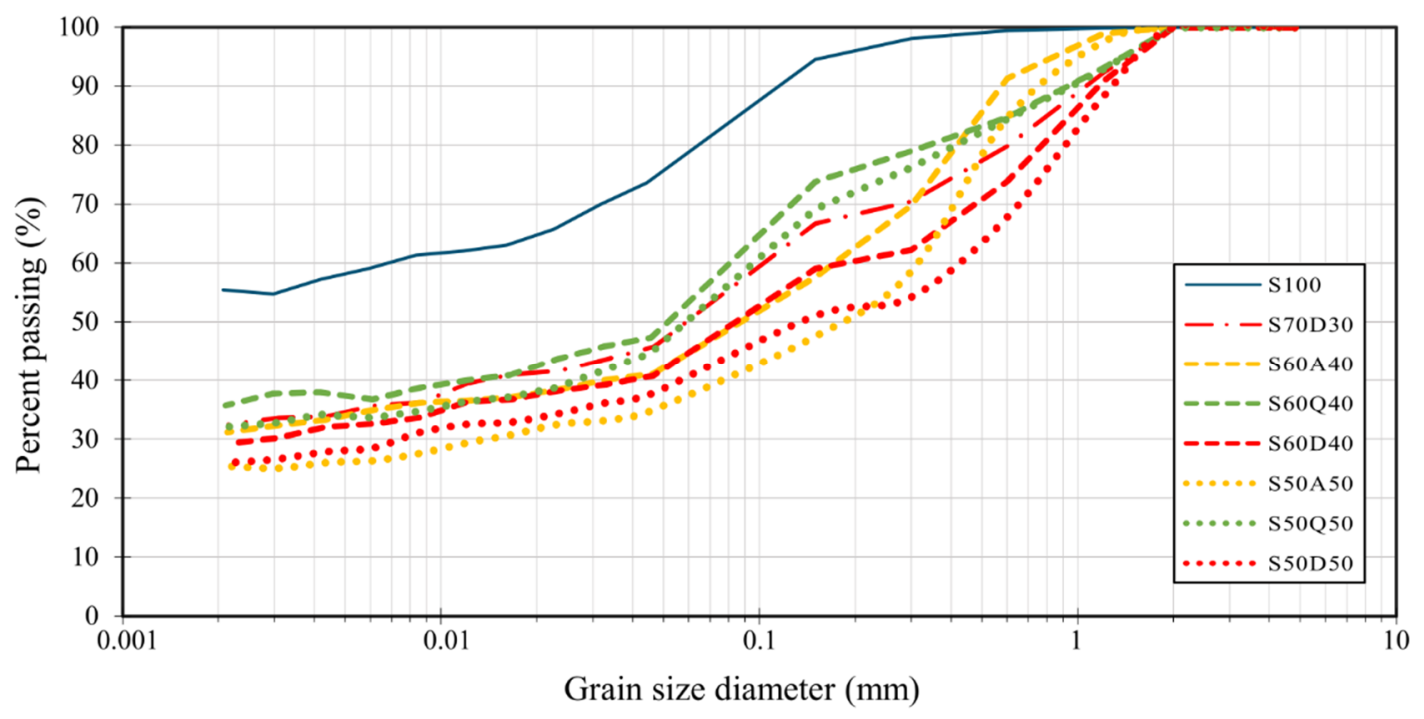

Figure 2. Grain size distribution curve of the samples

Table 1 - Grain size analysis of the samples

\begin{tabular}{ccccc}
\hline Sample & Clay (\%) & Silt (\%) & Sand (\%) & Gravel (\%) \\
\hline S100 & 55 & 24 & 21 & 0 \\
S70D30 & 32 & 18 & 50 & 0 \\
S60A40 & 31 & 14 & 55 & 0 \\
S60Q40 & 35 & 18 & 47 & 0 \\
S60D40 & 29 & 16 & 55 & 0 \\
S50A50 & 26 & 12 & 62 & 0 \\
S50Q50 & 32 & 18 & 50 & 0 \\
S50D50 & 26 & 15 & 59 & 0 \\
\hline
\end{tabular}

Table 2 - Proctor Compaction test of the samples

\begin{tabular}{|c|c|c|}
\hline Sample & Optimum water content (\%) & Maximum dry density $\left(\mathrm{g} / \mathrm{cm}^{3}\right)$ \\
\hline S100 & 26.60 & 1.51 \\
\hline S70D30 & 20.00 & 1.71 \\
\hline S60A40 & 19.50 & 1.73 \\
\hline S60Q40 & 19.10 & 1.73 \\
\hline S60D40 & 19.30 & 1.71 \\
\hline S50A50 & 15.60 & 1.81 \\
\hline S50Q50 & 18.70 & 1.74 \\
\hline S50D50 & 16.50 & 1.77 \\
\hline
\end{tabular}

Table 3 - MCT Classification of the samples

\begin{tabular}{|c|c|c|c|c|c|}
\hline Sample & $\mathbf{c}^{\prime}$ & $d^{\prime}$ & $\mathrm{Pi}$ & $\mathbf{e}^{\prime}$ & МСT Classification \\
\hline S100 & 1.90 & 87.74 & 42 & 0.87 & LG' - Lateritic Clayey \\
\hline S70D30 & 1.40 & 245.0 & 42 & 0.79 & LA' - Lateritic Sandy \\
\hline S60A40 & 1.40 & 28.75 & 0 & 0.89 & LA' - Lateritic Sandy \\
\hline S60Q40 & 1.40 & 51.18 & 0 & 0.73 & LA' - Lateritic Sandy \\
\hline S60D40 & 1.40 & 63.88 & 12 & 0.76 & LA' - Lateritic Sandy \\
\hline S50A50 & 1.30 & 83.13 & 25 & 0.79 & LA' - Lateritic Sandy \\
\hline S50Q50 & 1.30 & 29.18 & 37.2 & 1.02 & LA' - Lateritic Sandy \\
\hline S50D50 & 1.40 & 101.67 & 18 & 0.72 & LA' - Lateritic Sandy \\
\hline
\end{tabular}




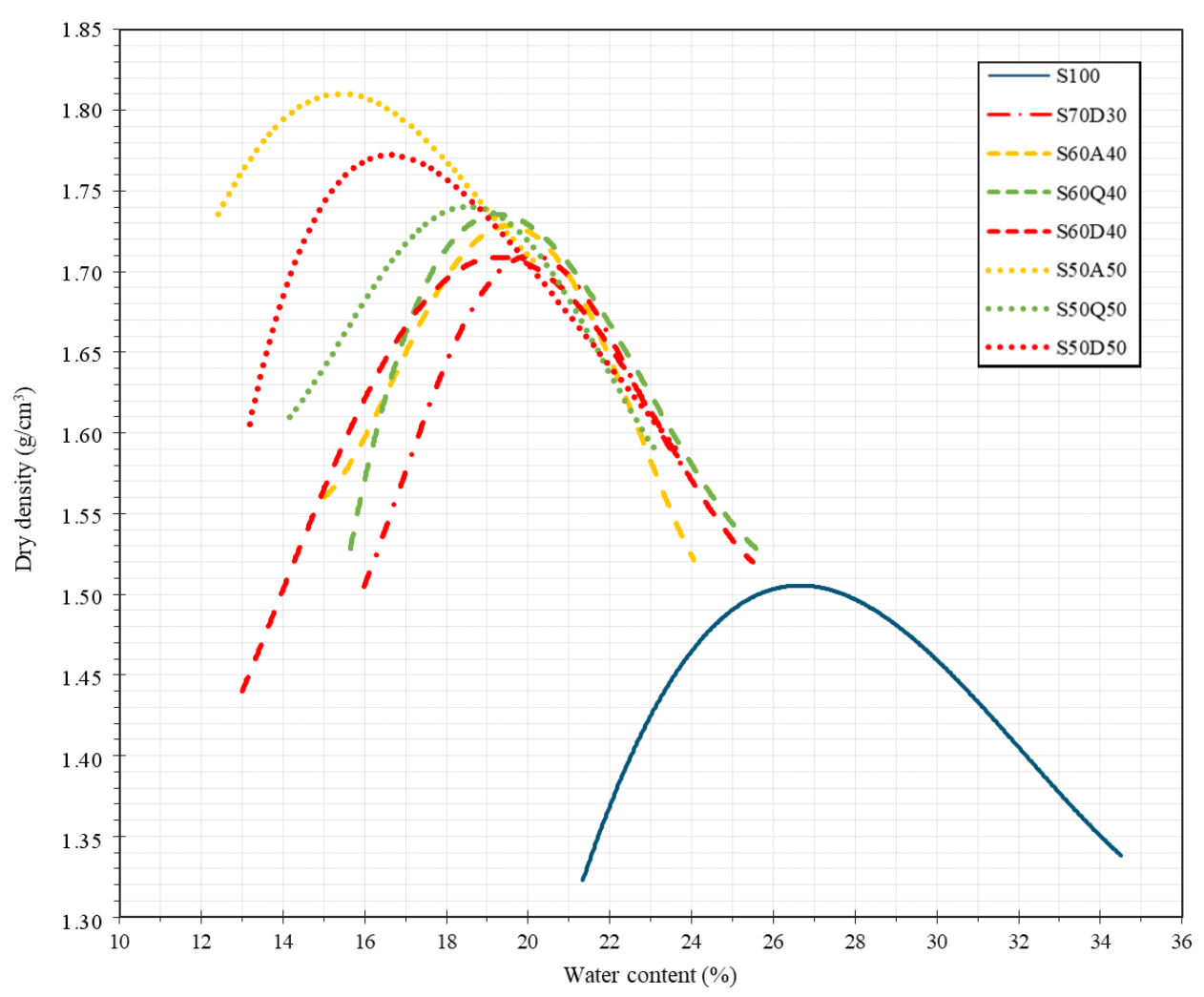

Figure 3. Proctor compaction curves of the samples

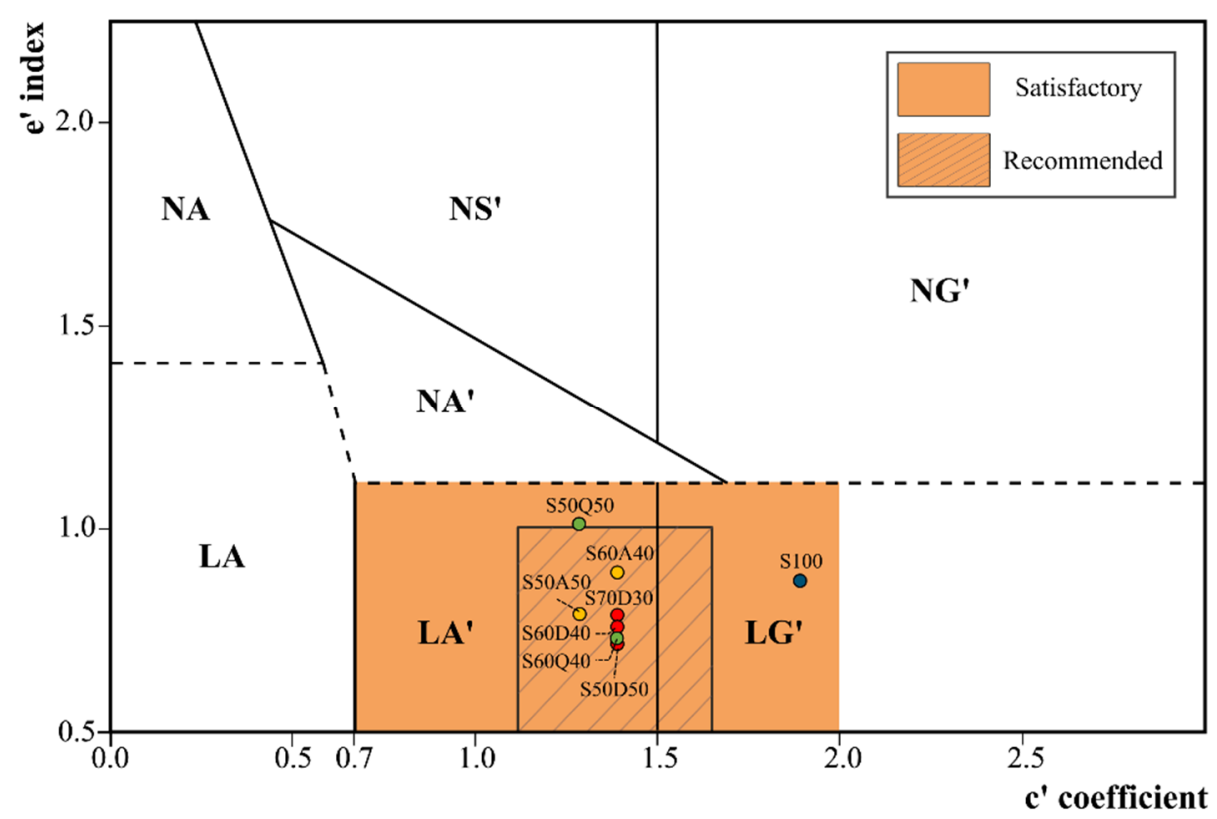

Figure 4. Location of mixtures in the MCT abacus Classification

The results were evaluated based on the MCT classification, since this is the most recommended in Brazil for low-cost paving (Nogami and Villibor, 2009). In this context, it was used the abacus classification of Nogami and Villibor (2009), which delimits areas suggesting "Recommended and Satisfactory" classification.

When plotting the results (Figure 4), it is observed that the natural soil, Lateritic Clayey (LG'), commonly found in the rural area of Passos, State of Minas Gerais, fits in the "Satisfactory" field 
and may present geotechnical characteristics suitable for use in road base and sub-base, while mixtures, with the exception of the sample with 50\% quartzite, fall into the "Recommended" field.

The mixture using 40\% quartzite and all samples containing dunite powder mixed with the Lateritic Clay Soil (LG') improved the material conditions, since it moved from the "satisfactory" material area to "Recommended" material in the MCT abacus classification (Nogami and Villibor, 2009);

Based on the results obtained in the Proctor compaction test (Table 2), the addition of sand (traditional aggregate), fine fraction of the quartzite mining tailings and dunite powder resulted in a reduction of the optimum water content and the increase in the apparent maximum dry density when compared to the parameters obtained for natural soil.

In view of these findings, it appears that the mixtures tested, with the exception of $50 \%$ quartzite, improved the conditions of the natural soil for use as base and sub-base, according to the criteria of Nogami and Villibor (2009).

\section{CONCLUSION}

a) both fine fraction of the quartzite mining tailings and dunite powder, in appropriate proportions, considering the criteria presented by Nogami and Villibor (2009), can replace sand in mixtures with the Lateritic Clay Soil ( $\mathrm{LG}^{\prime}$ ), for use in road base and sub-base layers, thus giving a proper destination to these materials that are commonly found in the mining send-off in the region;

b) considering minimizing the impact and optimizing the use of materials discarded by mining operations, it is recommended to use the largest possible amount of these residues in the mixtures; therefore, the most recommended proportions among those studied in this study are: $60 \%$ soil $+40 \%$ quartzite and $50 \%$ soil $+50 \%$ dunite powder;

c) additional studies, specific to the MCT Classification, as well as mechanical tests, especially the CBR and/or the Mini-CBR, recommended for base and sub-base of highways, should be conducted to confirm the effective use of these materials in the works.

\section{REFERENCES}

ABNT (2018) NBR 7181: Solo - Análise Granulométrica. Associação Brasileira de Normas Técnicas, Rio de Janeiro. ABNT (2020) NBR 7182: Solo - Ensaio de Compactação. Associação Brasileira de Normas Técnicas, Rio de Janeiro.

Alecrim, A. V. e G. T. P. Fabri (2004) Aproveitamento de Rejeitos da Mineração de Quartzitos do Sudoeste de Minas Gerais em Sub-bases e Bases de Pavimentos Flexíveis. Anais do 1 o Simpósio Brasileiro de Jovens Geotécnicos, 1, GEO-JOVEM, EESCUSP/ABMS, São Carlos-SP, p. 36-41.

Alecrim, A. V.; G. T. P. Fabri; L. L. B. Bernucci e E. Moura (2006) Estudo de Alternativa para o Aproveitamento de Rejeitos da Exploração de Quartzitos do Sudoeste Mineiro em Sub-base e Base de Pavimentos. Anais do Congresso Brasileiro de Mecânica dos Solos e Engenharia Geotécnica, COBRAMSEG, ABMS, Curitiba-PR, v. 1, p. 227-232.

Alecrim, A. V. (2009) Estudo do Resíduo de Quartzito Foliado para Emprego em Estruturas de Pavimentos. Dissertação de Mestrado em Engenharia de Transportes, Escola Politécnica, Universidade de São Paulo, São Paulo-SP. DOI: 10.11606/D.3.2009.tde-08092010-124250

Alecrim, A. V.; G. T. P. Fabbri; L. B. Bernucci e E. Moura (2009) Estudo do Resíduo de Quartzito para Emprego em Sub-base e Base de Pavimentos. Anais da 16ª Reunião de Pavimentação Urbana, Resumos, ABPv, Belo Horizonte-MG.

Batalione, G. e L. F. M. Ribeiro (2010) Análise da Viabilidade de Utilização de Rejeitos da Produção de Agregados em Pavimentos Rodoviários. Anais do 15 Congresso Brasileiro de Mecânica dos Solos e Engenharia Geotécnica, 5ํo Congresso

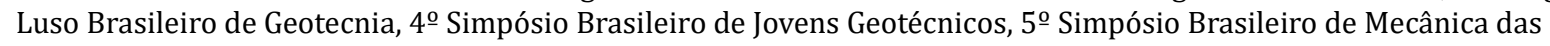
Rochas, ABMS, Gramado-RS.

Bernucci, L. B.; J. A. P. Ceratti; L. M. G. Motta e J. B. Soares (2010) Pavimentação Asfáltica: Formação Básica para Engenheiros. 3ํㅡㄹ Reimpressão. Petrobras, Abeda, Rio de Janeiro. ISBN: 8585227842. 
Colladetti, M. F. S. e A. C. Z. B. Collares (2015) Verificação do Uso de "Pó de Brita” Adicionado ao Solo para Base de Pavimentos. Monografia - Trabalho de Conclusão de Curso - Engenharia Civil. Universidade do Estado de Minas Gerais, UEMG, PassosMG.

Collares, E. G.; I. Francklin Júnior; R. F. Ramirio e D. R. P. Pamplona (2008a) Caracterização Tecnológica de Rejeitos de Minerações de Quartzitos do Sudoeste de Minas Gerais para Utilização como Agregado na Construção Civil. Anais do $12^{\circ}$ Congresso Brasileiro de Geologia de Engenharia e Ambiental, ABGE, Porto de Galinhas-PE.

Collares, E. G.; R. F. Ramirio; D. R. P. Pamplona I. e Francklin Júnior (2008b) Estudo comparativo de rejeitos de quartzito com outros agregados comercialmente utilizados como materiais de construção no Sudoeste de Minas Gerais. Ciência et Praxis. Passos-MG, v. 1, n. 1, p.10. ISSN (online): 1983-912X. ISSN (impressa): 1984-5782.

Collares, E. G.; I. Francklin Júnior e L. A. C. Motta (2012) Evaluation of the Aggregate Produced from Wastes of Quartzite Mining Sites to Use in Concrete. Soils and Rocks: An International Journal of Geotechnical and Geoenvironmental Engineering, São Paulo, v. 35, n. 3, p. 251-266. ISSN 1980-9743.

DNER-ME 256 (1994) Solos Compactados em Equipamento Miniatura - Perda de Massa por Imersão. Departamento Nacional de Estradas de Rodagem, Rio de Janeiro.

DNER-ME 258 (1994) Solos Compactados em Equipamento Miniatura - Mini-MCV. Departamento Nacional de Estradas de Rodagem, Rio de Janeiro.

DNER-PRO 003 (1994) Coleta de Amostras Deformadas de Solo. Departamento Nacional de Estradas de Rodagem, Rio de Janeiro.

Faria Júnior, Í. R. (2011) Modelo Estrutural da Mineralização na jazida Morro do Níquel, Pratápolis, MG. Monografia - Trabalho de Conclusão de Curso - Geologia. Instituto de Geociências e Ciências Exatas, Universidade Estadual Paulista, Rio Claro-SP.

FEAM (2011) Fundação Estadual do Meio Ambiente.

Francklin Júnior, I. (2009) Estudo Tecnológico em Rejeitos de Quartzitos do Sudoeste de Minas Gerais para Utilização como Agregado Graúdo no Concreto. Dissertação de Mestrado em Engenharia Civil, Universidade Federal de Uberlândia, Uberlândia-MG. https://repositorio.ufu.br/handle/123456789/14139.

Francklin Júnior, I.; L. A. C. Motta; E. G. Collares e T. J. Silva (2010) Estudo de Concretos Produzidos com Agregado Graúdo de Quartzito Proveniente de Resíduos de Minerações do Sudoeste Mineiro. Anais do $52^{\circ}$ Congresso Brasileiro do Concreto, IBRACON, Fortaleza-CE.

Grilo, S. M. S. (2016) Estudo da Viabilidade de Uso do Rejeito Fino de Quartzito para Pavimentação. Dissertação de Mestrado Profissional em Desenvolvimento Regional e Meio Ambiente. Universidade do Estado de Minas Gerais, Passos-MG.

Nogami, J. S. e D. F. Villibor (1995) Pavimentação de Baixo Custo com Solos Lateríticos. Ed. Vilibor, São Paulo, 213 p.

Nogami, J. S. e D. F. Villibor (2009) Pavimentos Econômicos: Tecnologia do Uso dos Solos Finos Lateríticos. Ed. Arte \& Ciência, São Paulo. ISBN 978-85-61165-34-5

Reis, M. J. (2016) Avaliação Tecnológica de Rejeitos de Minerações de Quartzito do Sudoeste Mineiro como Agregados em Peças de Concreto para Pavimentação (PCP), 2016. 207f. Dissertação de Mestrado em Desenvolvimento Regional e Meio Ambiente, Universidade do Estado de Minas Gerais, Passos-MG.

Reis, M. J.; E. G. Collares e F. M. D. Reis (2018a). Technological Assessment of Tailings from Quartzite Mining Sites in Alpinópolis (Minas Gerais-Brazil) as Aggregates in Concrete Block Paving (CBP). Bulletin of Engineering Geology and the Environment, v. 77, n. 4, p. 1623-1637. DOI: https://doi.org/10.1007/s10064-017-1015-6

Reis, F. M. D.; E. G. Collares e M. J. Reis (2018b) Estudo Tecnológico em Rejeitos de Minerações de Quartzitos do Sudoeste Mineiro para Uso como Agregado em Pavimentação Urbana. Anais do 16 Congresso Brasileiro de Geologia de Engenharia e Ambiental, CBGE, São Paulo. ISBN 978-85-7270-076-4.

Russo, M. L. C. (2011) Reciclagem de Resíduo Gerado na Extração de Quartzito. Tese de Doutorado, Escola de Engenharia, Universidade Federal de Minas Gerais, UFMG, 172 f., Belo Horizonte-MG. 1843/BUOS-8RRFAS

Santana, H. (1993) Introdução à mecânica dos pavimentos de baixo custo. Anais da 27ạ Reunião Anual de Pavimentação., ABPv, Teresina-PI, p. 488-521.

Tonidandel, R. P. (2011) Aspectos Legais e Ambientais do Fechamento de Mina no Estado de Minas Gerais. Dissertação de Mestrado em Geologia, Instituto de Geociência, Universidade Federal de Minas Gerias, Belo Horizonte-MG. 1843/MPBB8LMGN5

Villibor, D. F.; J. S. Nogami; J. R. Cincerre; P. R. M. Serra e A. Zuppolini Neto (2009) Pavimentos de Baixo Custo para Vias Urbanas. 2. ed. Arte \& Ciência, São Paulo. ISBN 978-85-61165-29-1. 